\title{
METHODICAL APPROACH TO DETERMINATION OF LEVEL OF INNOVATION COMPETITIVENESS OF CONSTRUCTION ENTERPRISES
}

\author{
Pavlo Fisunenko'
}

\begin{abstract}
The purpose of the paper is to develop and prove the combined methodical approach to estimation of the level of innovation competitiveness of construction enterprises. Methodology. Theoretical and methodical basis of the research is the system approach to study of fundamental concepts of economic science to providing enterprises' competitiveness. Development of the combined methodical approach is based on the results of comparative analysis of the existing approaches to estimation of companies' competitiveness, including researches of the methods assessing total competiveness as well as its separate components. Dialectical and abstract logical methods as well as induction and deduction were used to generalize theoretical and methodological aspects of competitiveness evaluation and develop the combined approach. The results of the comparative analysis of publications devoted to estimation of enterprises' competitiveness showed that the approach used by the researchers is based on using one or several methods of evaluation: based on the competitive advantages theory, effective competition, quality of goods, matrix, integral, scoring, analytical hierarchy, VIKOR and others. All these methods that can be used to estimate innovation competitiveness of construction companies are divided into three groups: quantitative, qualitative, and specialized. A combined approach to estimation of construction enterprises' competitiveness based on combination of methodical concepts of stakeholder analysis theory (interested parties) using comparative advantage, matrix and integrated methods. Practical implications is development of scientific, methodological and practical approach to estimation of construction enterprises' competitiveness allowing to receive the basis to creating the strategy of innovation competitiveness in order to provide economical safety. Value/originality is development of theoretical, methodological and applied aspects of estimation construction enterprises' competitiveness including combined methodical approach as a complex of separate blocks, each is aimed at solving separate research task and has one purpose.
\end{abstract}

Key words: enterprise, competitiveness, level, estimation, method.

JEL Classification: D20, O31, L74

\section{Introduction}

Determination of the level of the enterprise's innovative competitiveness is the basic moment for the strategy of innovation competitiveness development in order to prove its economical safety. Researches and scientific analysis of the materials studying innovative competitiveness allowed to determine that innovative competitiveness was an aggregated characteristic of fulfilling innovative activity and competitive advantages as its result that are company's assets and parameters forming its positive differences comparing to competitors due to innovative activity. Estimation of the enterprise's innovation competitiveness is assessing its ability to develop and use innovations in order to gain competitive advantages at the certain market and determine its level which is a complicated task of interpretation and estimation of aspects that characterize enterprise's innovative activity that forms its innovative competitiveness.

Determination of the level of the enterprise's innovation competitiveness should facilitate: motivation for managerial decisions, determination the ways of increasing innovative management and production, modernization of technology, implementation of modern innovative instruments, financing innovations and organizational provision of their using, development the ways

\footnotetext{
Corresponding author:

${ }^{1}$ Prydniprovska State Academy of Civil Engineering and Architecture, Ukraine.

E-mail: fisunenko.pavlo@pgasa.dp.ua

ORCID: https://orcid.org/0000-0002-1339-5860
} 
of costs optimization, increasing customer focus of innovations that helps to succeed in the competition for the customer and sales market. Multilevel character of competitive interaction of construction companies causes wide range of approaches to estimation of their innovation competitiveness.

\section{Comparative analysis of the existing approaches to estimation}

Considering the fact that nowadays there are no accepted methodological approaches to estimation of enterprises' innovation competitiveness, meanwhile characteristics and specific activity of every construction company causes necessity of careful choice of the estimation method of its general competitiveness or its separate elements, we have carried out comparative analysis of existing works in the sphere of estimation of enterprises' competitiveness. The results of comparative analysis of publications devoted to estimation of enterprises' competitiveness showed that the approach used by researchers are based on one or several methods of estimation. The variety of methods of enterprises' competitiveness evaluation used by the researchers caused necessity of their generalization and systematization in order to choose the most appropriate ones to assess construction companies' competitiveness.

Based on the analysis of the existing works (Sakhno, 2012), the largest groups of methods of companies' competitiveness evaluation based on the theories of comparative advantages, effective competitiveness, quality of the product, matrix and integral were determined. It is offered to estimate enterprises' competitiveness on the basis of scoring method of rating model using methods of multicriteria analysis (Balan \& Anisimova, 2011).

The work presents estimation of competitiveness using instruments of multicriteria optimization, in particular methods of analytic hierarchy (T. Saati) and VIKOR (Balan \& Prymak, 2014).

V. Oberemchuk, D. Yatskoviy, H. Ivaschenko, O. Mlotok developed their methodological approaches based on the theory of effective competition. According to this theory, the most competitive enterprise is the one with the best organization of financial, production and sales activity. Based on assessing of indices of enterprises' effective activity, financial state, effective sales organization enterprise competitiveness ratio is determined.
According to the theory of effective competitiveness widening the list of standard indices such directions of estimation were proposed: competitiveness of product, financial state of an enterprise, effectiveness of promotion and sales, effectiveness of production, enterprises' competitive potential, production ecological compatibility, social effectiveness, image of the enterprise (Oberemchuk, 1999).

The methodological approach to competitiveness estimation based on enlargement of indices developed by V. Oberemchuk includes six groups: production effectiveness, business activity, financial state, effectiveness of promotion and sales, effectiveness of investment and innovative activity, position on securities market was proposed (Yatskovyi, 2013).

It was proposed to estimate the company's competitiveness in such areas: effectiveness of production activity, effectiveness of financial activity, effectiveness of human resources management, effectiveness of innovation activity, effectiveness of marketing activity (Ivashchenko, 2004).

Methodological approach offered by O. Mlotok, is also based on methods of effective competition theory and deals with four areas: effectiveness of production activity, financial state, effectiveness of promotion and sales, competitiveness of the product. It deals with the most important spheres of the company's activity and excludes doubling separate indices (Mlotok, 1998).

Estimation of the company's competitiveness is based on assessing their financial condition, efficiency of their economic activity and products competitiveness (Lupak, 2010; Yevchuk, 2010). Company's financial stability is used besides mentioned above estimation (Shhiborshh, 2000).

Estimation of enterprise's competitiveness is based on methods of marketing and financial analysis and includes calculating ratio of marketing testing of competitiveness characterizing effectiveness of marketing activity as well as current ration and equity to non-current assets ratio (Bilousov, 2010).

\section{Groups of methods estimating enterprise's competitiveness}

Therefore, all the methods for estimation companies' competitiveness used for assessing innovative competitiveness of construction 
companies can be divided into three groups: quantitative, qualitative and specialized.

Qualitative methods are basically used in conditions of limited statistic data. They include method of expert survey determining nature of market phenomenon, factors influencing the company's competitiveness and other qualitative characteristics of its activity. Among them there are SWOT analysis, SNW analysis, PEST analysis and stakeholders' analysis. Quantitative methods have high level of mathematic formalization, estimation accuracy and objectivity. They are based on quantitative indices. The information basis for these methods is financial, accounting, statistic data of the company. Specialized methods allow to estimate the competitiveness of separate aspects of the company's activity - production, innovation, marketing, financial, etc.

Methodological aspects of the complex estimation of enterprise's competitiveness is presented in the work of A. Levytska, having formed complex approach when using complex of methods of enterprise's competitiveness to get deeper evaluation (Levytska, 2013).

\section{Combined approach to estimation of innovation competitiveness}

Despite considerable methodical development choice of the approach considering all aspects of enterprise's innovation activity and satisfying interests of all interested parties of construction enterprise is still actual nowadays.

Logics of the proposed methodological approaches is doubtless considering theoretical issue, however it is necessary to provide its flexibility and alternative options of different methods using in specific economic conditions of enterprises' functioning due to lack of official information concerning innovative activity of construction enterprises. This will allow to get full information about the level of innovation competitiveness of construction enterprises comparing with others.

In our opinion, an approach based on combination of methodical aspects of the theory of stakeholders' analysis (interested parties) using methods of comparative advantages, matrix and integration methods can satisfy all these demands. Therefore, while assessing

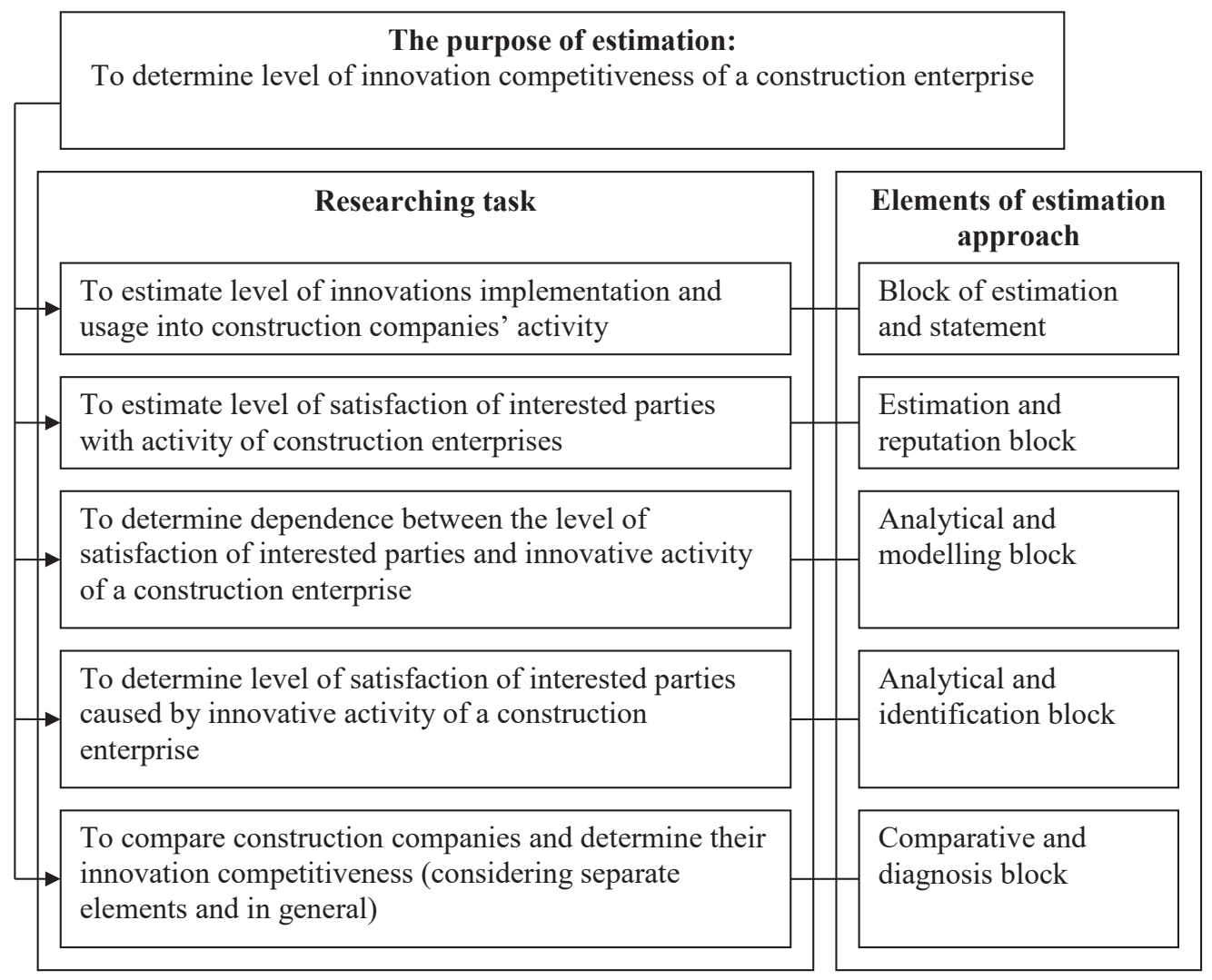

Figure 1. Elements of the combined methodological approach to estimation of innovative competitiveness of construction enterprise considering interested parties 
construction enterprises' innovation competitiveness it is necessary to use a combined methodical approach, based on using different elements combinations of existing methodical approaches adding each other and it demands survey of different interested parties, analysing their opinions and determining regularity.

Such a methodological approach is offered to present as a complex of separate blocks, each aiming at solving a separate research task and leading to the same purpose (Figure 1).

The first one is block of estimation and statement providing estimation of the level of implementation and using innovations (technological, organizational and managerial) in the construction company's activity by means of scoring estimation. When conducting a survey of the construction company's employees of different categories (managers, specialists, workers) it is offered to estimate the level of implementation of different types of innovations.

The second one is estimation and reputation block providing scoring of satisfaction level of the interested parties considering the company's activity and determining the average level of satisfaction of each interested party and aspect of activity.

Next is analytical and modelling block determining dependence between estimation of the satisfaction level of the interested parties and assessing its innovation activity. In order to provide this, it is necessary to use methods of correlation and regression analysis and mathematical modelling.

Next is analytical and identification block determines the satisfaction level of the interested parties caused by innovation activity of construction enterprise.

Last is comparative and diagnosis block providing determination of the level of construction enterprise's innovative competitiveness (comparing with other enterprises) based on general indicator.

\section{Conclusions}

The researches carried out allowed to make such conclusions:

1. Estimation of the company's innovative competitiveness was the necessary stage of developing the strategy for its economic safety provision.

2. Comparative analysis of the existing approaches to estimation of the company's competitiveness showed that they were based on using one or several methods of estimation.

3. It was determined that all methods of the estimation of the company's competitiveness could be divided into three groups: quantitative, qualitative, and specialized.

4. The approach based on combining theory of stakeholders analysis using method of competitive advantages, matrix and integral method, was used to estimate innovation competitiveness of construction companies.

5. Elements of the combined methodological approach to estimation of the construction company's innovation competitiveness considering interested parties are analysed.

The prospects of the further research in this direction is mathematical formalization of the proposed method and its approbation on the construction companies. The results of estimation of innovative competitiveness will be considered while developing the ways of providing construction company's economic safety.

\section{References:}

Balan, V., \& Anisimova, L. (2011). Methodical provision of estimation of competitiveness of enterprises. Teoretychni ta prykladni pytannia ekonomiky, vol. 25, pp. 23-31.

Balan, V., \& Prymak, V. (2014). VIKOR method in comparative analysis of enterprise competitiveness. Pratsi Mizhnarodnoi naukovo-praktychnoi konferentsii Konkurentospromozhnist ta innovatsii: problemy nauky ta praktyky.

Bilousov, V. (2010). Otsinka konkurentospromozhnosti firmy. Marketynh za kordonom, vol. 6, pp. 109-119.

Ivashchenko, H. (2004). Methodology for assessing the level of competitiveness of enterprise. Ekonomika rozvytku, vol. 3(31), pp. 94-97.

Levytska, A. (2013). Methods for assessing competitiveness: national and international approaches to classification. Mechanism of Economic Regulation, vol. 4, pp. 155-163.

Lupak, R. (2010). Economic bases of ensuring the competitiveness of the enterprise in market relations. Naukovyi Visnyk NLTUU, vol. 20.6, pp. 248-252. 
Mlotok, E. (1998). Principles of marketing research of competition in the market. Retrieved July 17, 2020, from: http://www.marketing.spb.ru/read/m3/

Oberemchuk, V. (1999). Ensuring the competitiveness of the enterprise: strategic aspects. Extended abstract of $P h D$ dissertation. Kiev: Vernadsky National Library of Ukraine. (in Ukrainian)

Sakhno, I. (2012). Analysis of key methodological approaches to the assessment of the competitiveness of enterprises. Zbirnyk naukovykh prats Tavriiskoho derzhavnoho ahrotekhnolohichnoho universytetu, vol. 2, pp. 385-390.

Shhiborshh, K. (2000). Sravnitelnyi analiz konkurentosposobnosti i finansovogo sostoianiia predpriiatiia otrasli i/ili regiona. Retrieved July 17, 2020, from: http:// https://www.cfin.ru/press/marketing/2000-5/12.shtml Yatskovyi, D. (2013). Modern methods of enterprise competitiveness assessment. Visnyk sotsialnoekonomichnykh doslidzhen, vol. 4(51), pp. 183-188.

Yevchuk, L. (2010). Stratehii zabezpechennia konkurentospromozhnosti silskohospodarskykh pidpryiemstv. Extended abstract of PhD dissertation. Kiev: Vernadsky National Library of Ukraine. (in Ukrainian) 